yellow spots-one (a large one) in the cell, one at the apex trifid, one between this and the outer margin, one divided by the second median nervule, and the fifth near the inner margin. Posterior wing with three orange-yellow spots-one partly in the cell bifid, and two below it.

Underside. Anterior wing as above, except that the costal margin from the base to the middle is orange, and that the nervures near the outer margin are yellow. Posterior wing yellow, spotted throughout with black : a band of black near and parallel to the inner margin.

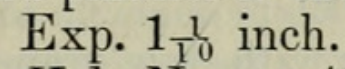

Hab. Nyassa (Thelwall and Simons).

Nearest to C. Makomo.

\title{
Cyclopides Dardaris.
}

Alis utrinque fuscis: anticis macula media triangulari punctisque tribus minutis hyalinis albis: posticis punctis duobus albis in medio positis : ambarum infra marginibus flavis: posticis punctis nonnullis flavis.

Upperside dark brown, with the fringe rufous-white. Anterior wing with four white transparent spots-one central (rather large, triangular, bifid), the other three very minute, two near the apex, and one below them. Posterior wing with two small central white spots.

Underside as above, except that both wings have the outer margin and the end of the nervures yellow, and that the posterior wing is marked by several yellow spots.

Exp. $\frac{8}{10}$ inch.

Hab. Mexico.

\section{XLI.-Capture of a Right Whale in the Mediterranean. By Alban Doran.}

As interesting monograph has been recently published by Professor Capellini of Bologna, entitled "Della Balena di Taranto, confrontata con quelle della Nuova Zelanda e con talune fossili del Belgio e della Toscana." From a perusal of this treatise it appears that on Feb. 9th of this year a whale was observed in the Gulf of Taranto by Mr. Ferdinand Hueber. This gentleman called the attention of some sailors to the cetacean; and it was at length killed close to the town of Taranto, after being repeatedly fired at and finally disabled by a dynamite cartridge. 
The authorities referred to the minister of Public Instruction, who, after much deliberation, made over this interesting specimen to the University of Naples; but while it was in process of maceration, Signor Capellini was permitted to make and publish some valuable observations.

This whale was a young female, 12 metres in length, of rather slender outline, the rostrum rather curved, the baleenplates short. The stomach was quite empty, and its mucous membrane thrown into folds.

The cranium measured about 2.50 metres, the vertebral column about $9 \cdot 50$ metres; similar proportions, remarks the author, are seen in Gray's Macleayius australiensis. It had 7 cervical, 14 dorsal, and 36 lumbar and caudal vertebræ-in all 57 .

Professor Capellini observes that Van Beneden had admitted the existence of a distinct recent species of Balcena, differing from the $B$. australis and $B$. antipodum of the southern hemisphere. This is the "black whale,", wellknown to whalers; yet no skeleton of this species has been examined by any anatomist. The Tarentine whale probably, in the opinion of the author, belongs to the above undescribed species. After details, presently to be more fully noticed, he thus epitomizes the characters of the "Balcena tarentina:"

"Head and fins different in form from the same in $B$. biscayensis and mysticetus; colour entirely black; parasites of the rostrum and lips of the same species as in the whales of the southern hemisphere; nasal bones of the typical form seen in whales of that hemisphere; baleen-plates 240 in number, short in every measurement; vertebra 57 . The vertebræ of the cervical region incompletely ankylosed, the condyles of the atlas bevelled on their inner aspects, corresponding to the spinal canal; the fourth, fifth, and sixth cervical vertebræ have a fissure several millimetres deep on the lower aspect of their bodies, the seventh is free; the scapula is broader than long."

In describing the skull, Professor Capellini states that, though smaller, it reminded him of the cranium of B. australis, and, better still, that of Macleayius australiensis, Gray, from which it seems to differ in trifling points only. The occiput is like that of the author's new fossil genus Idiocetus, in which the atlas is intermediate between the same in Balcena and Balcenoptera. It measures from its anterior extremity to the upper border of the foramen magnum 0.62 metre. There is a distinct occipital crest. The frontal bone projects 12 centims. from the anterior extremity of the occipital bone to the 
posterior border of the nasal. The nasal bones present the characters described by Professor Flower as typical in Eubalaena, and still more remind Professor Capellini of the same bones in Macleayius. They are short and broad, concave anteriorly, and quite unlike those of $B$. mysticetus.

The tympanic bone of this $B$. tarentina differs from that of $B$. australis in the form of the curve of the inner margin and in the form of the columellar projection on the lip close to the meatus ; moreover it is gibbous behind as in $B$. japonica, but less inflated than in $B$. australis, still less than in $B$. antipodum. The petrous bone is of the ordinary Balcena type. The malleus is lost; but Signor Capellini figures the incus and stapes, which are of the same form as specimens of the corresponding bones in B. australis and mysticetus in the museum of the Royal College of Surgeons of England. Judging from the engraving, the incus has no affinities to the highly characteristic representative of that ossicle in Balcenoptera and nearly all other cetaceans.

The mandible of $B$. tarentina does not very closely resemble that of $B$. australis, but is similar to the same bone in the fossil Idiocetus Guicciardini and in Balcenotus. Its rami are well bowed outwards anteriorly, as in the other right whales. The myloid groove is much deeper than in any other existing Balcena, recalling a character observed in the fossil Balcenotus of Belgium and Tuscany. The length of each ramus, following the external curve, is 2.50 metres; the height of each condyle 0.24 metre. There are six mental foramina on each side; the distance between them diminishes regularly towards the most posterior. The longest baleen-plates measured by Professor Capellini are 0.76 metre long, following the curve of their inner margin. They form two masses of 240 plates each, the longest, of which the measurement has just been quoted, were in the middle of each mass. The author declares that they are in pattern unlike those of any other whale, although he has inspected the large collection of baleen-plates at Vienna.

The seventh cervical vertebra is quite free. This region (except in that respect) much resembles the same in Gray's Macleayius; only, instead of the complete freedom of the atlas seen in that New-Zealand whale, the first cervical vertebra in B.tarentina is distinct above, but ankylosed to the second below, as in Idiocetus. The axis and the four succeeding vertebræ are also fused inferiorly only; the separation above is very distinct between the fourth and fiftb and the fifth and sixth; such is the case in Balcenotus and Balcenula. There is a peculiar fissure running along the under surface of the bodies 
of the last four ankylosed cervical vertebræ; this is deepest at the most posterior.

The scapula is somewhat intermediate in type between that of Balcena and Balcenoptera, more particularly B. Sibbaldi.

Professor Capellini expresses a strong belief that this whale came from the southern seas, not only from its australoid characters, but also on account of the southern species of parasites on its body, and from its stomach being empty and wrinkled through long fasting (aggrinzito per lungo digiuno), showing that it had wandered far from its natural feeding place. As every rule has exceptions, so, remarks the Italian Professor, we may believe that these great vertebrates, with their powerful and rapid means of locomotion, may, though as a rule very local in their habitat, under exceptional circumstances, pass over from their side of the equator and invade the seas of the opposite hemisphere. The Tarentine whale offers a "splendid example" of this fact.

The monograph is accompanied by two plates, representing the bones described in the text, and by a coloured engraving of the whale from a water-colour taken after its capture by Mr. Hueber.

I understand that Professor Van Beneden has recently suggested that the whale above described is Baliena biscayensis.

XLII.-Notes on the Pearly Nautilus (Nautilus pompilius). By George Bennett, M.D., F.L.S.*

In the Address to the Biological Section of the British Association by J. Gwyn Jeffreys, LL.D., F.R.S., he says, " But Nautilus and Spirula are believed by some to be deep-water forms. This must be a mistake. Although the animal of that common species Nautilus pompilius has rarely been met with, the shells are often found on beaches in the Indian Ocean and South Pacific; and I am not aware of any instance of a deep-water mollusk being cast on shore." In this remark I perfectly agree, and I offer the following notes confirmatory of my opinion. In 'Nature' (11th Feb. 1875) there is a paper entitled "News from the "Challenger," " in which it is mentioned, "On the 24th of July we stopped off Matuka Island and landed a party of surveyors and naturalists ; and while they were taking observations and exploring

* Read at the Plymouth meeting of the British Association, and communicated by the author. 


\section{$2 \mathrm{BHL}$ Biodiversity Heritage Library}

Doran, Alban. 1877. "XLI._Capture of a right whale in the Mediterranean." The Annals and magazine of natural history; zoology, botany, and geology 20, 328-331. https://doi.org/10.1080/00222937708682240.

View This Item Online: https://www.biodiversitylibrary.org/item/63588

DOI: https://doi.org/10.1080/00222937708682240

Permalink: https://www.biodiversitylibrary.org/partpdf/59757.

\section{Holding Institution}

University of Toronto - Gerstein Science Information Centre

\section{Sponsored by}

University of Toronto

\section{Copyright \& Reuse}

Copyright Status: NOT_IN_COPYRIGHT

This document was created from content at the Biodiversity Heritage Library, the world's largest open access digital library for biodiversity literature and archives. Visit BHL at https://www.biodiversitylibrary.org. 